p-ISSN. 2086-9029

e-ISSN. 2654-5675

Vol. 22 No. 2, HIm. 159-352, Desember 2020

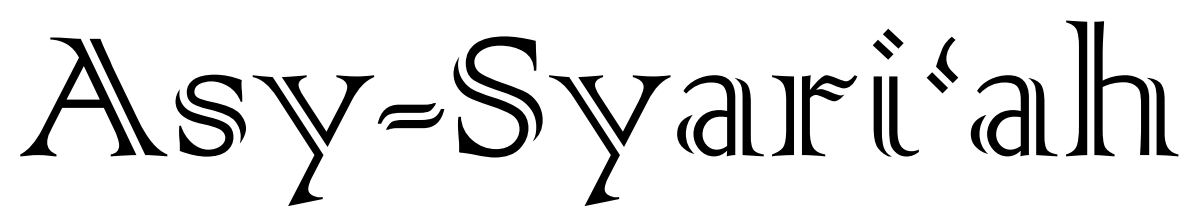

- Implementasi Prinsip Keadilan dalam Hukum Perjanjian Syari'ah

$(159-178)$ Zaenudin Mansyur

- Akad Rahn Tasyjili pada Gadai Tanah Pertanian di Pegadaian Syariah

$(179-196)$ Rahmadi Indra Tektona, Dyah Ochtorina Susanti

- Potensi Sertifikasi Halal dalam Mengahadapi Masyarakat Ekonomi

$(197-218)$ ASEAN

Deviana Yuanitasari, Helitha Noviana Dewi

- Akad Mudharabah sebagai Instrumen Pendanaan dan Pembiayaan di

$(219-236)$ Lembaga Keuangan Syariah

Asep Dadang Hidayat, Moh. Sar'an

- Praktik Rekayasa Dispensing Pump SPBU Persfektif Peraturan

$(237-258)$ Perundang-Undangan dan Hukum Islam

Hazar Kusmayanti, Ratu Chairunissa

- Dinamika Penerapan Akad Syariah dalam Produk Keuangan di Bank

$(259-274)$ Syariah

Jaenudin

- Etika Bisnis Islam pada Perilaku Pemasaran dan Kepuasan Konsumen

$(275-290)$ Wida Ramdania

- Kebijakan Fiskal Islam pada Masa Al-Khilafah Al-Islamiyah

Supriatna, Dedah Jubaedah

- Pelanggaran Prinsip Tanggungjawab Perusahaan Asuransi Investasi Persfektif Perundang-Undangan dan Hukum Ekonomi Syariah

Yoghi Arief Susanto, Yeti Sumiyati

- Identifikasi Kebutuhan Pembiayaan Syariah Peternak Lembu di Deli (337-352) Serdang

Marlya Fatira AK, Anriza Witi Nasution, Tuti Kurnia

FACULTY OF SHARIA AND LAW

STATE ISLAMIC UNIVERSITY SUNAN GUNUNG DJATI BANDUNG-INDONESIA IN COLLABORATION WITH ASOSIASI SARJANA SYARIAH INDONESIA 


\section{Asy-Syari'ah}

Volume 22, Number 2, 2020

\section{EDITOR-IN-CHIEF}

Ine Fauzia

\section{EDITORIAL BOARD}

Sofyan al-Hakim, UIN Sunan Gunung Djati Bandung, Indonesia Deni Kamaludin Yusup, UIN Sunan Gunung Djati Bandung, Indonesia

Meria Utama, Fakultas Hukum Univrsitas Sriwijaya, Indonesia

Dewi Mayaningsih, UIN Sunan Gunung Djati Bandung, Indonesia

Andrey Sujatmiko, Fakultas Hukum Universitas Trisakti, Jakarta, Indonesia

Hetty Hassanah, Universitas Komputer Indonesia, Indonesia

Tarun Ghawana, CDMS, New Delhi, India

Muhammad Hasanuddin, UIN Sunan Gunung Djati Bandung, Indonesia

Syahrul Anwar, UIN Sunan Gunung Djati Bandung, Indonesia

Aden Rosadi, UIN Sunan Gunung Djati Bandung, Indonesia

\section{PEER-REVIEWERS}

S. Salahudin Suyurno, Universiti Teknologi MARA (UiTM) Melaka, Malaysia

Ezani Yaakub, Universiti Teknologi MARA (UiTM) Malaysia, Malaysia

Zezen Zaenal Mutaqin, University of California, Los Angeles, United States

Muhammad Irfan Helmy, IAIN Salatiga, Semarang, Indonesia

Ahmad Ali Nurdin, UIN Sunan Gunung Djati Bandung

Tajul Arifin, UIN Sunan Gunun Djati Bandung, Indonesia

Mohamad Anton Athoillah, UIN Sunan Gunung Djati Bandung, Indonesia

Renny Supriyatni, Universitas Padjadjaran, Indonesia

Ahmad Tholabi Karlie, UIN Syarif Hidayatullah Jakarta, Indonesia

Ija Suntana, UIN Sunan Gunung Djati Bandung, Indonesia

Ahmad Fathonih, UIN Sunan Gunung Djati Bandung, Indonesia

Fauzan Ali Rasyid, UIN Sunan Gunung Djati Bandung, Indonesia

Rahman Syamsuddin, Universitas Islam Negeri Alauddin Makassar, Indonesia

\section{PROOFREADER/DESIGN COVER}

Nanang Sungkawa

\section{LAYOUT EDITOR}

Opik Rozikin

Asy-Syari'ah has been accredited by The Ministry of Education and Cultere, Republic of Indonesia as an academic journal in Sinta 3 (SK Diirjen Penguatan Riset dan Pengembangan Kemristekdikti No. 14/E/KPT/2019), valid for 5 years from Volume 19 No. 1 Tahun 2017 until Volume 23 No. 2 Tahun 2022. 


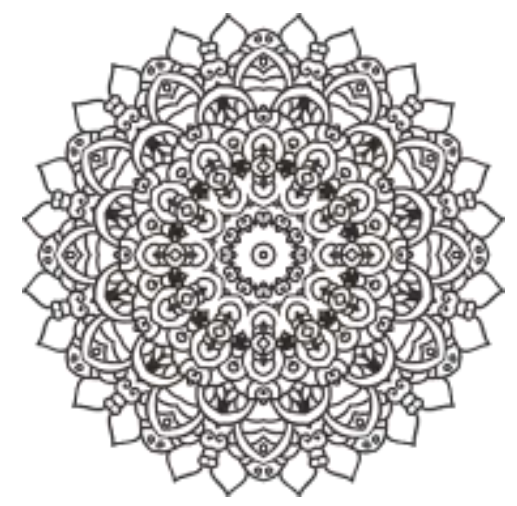

\title{
IDENTIFIKASI KEBUTUHAN PEMBIAYAAN SYARIAH PETERNAK LEMBU DI DELI SERDANG
}

\author{
${ }^{1}$ Marlya Fatira AK, ${ }^{2}$ Anriza Witi Nasution, ${ }^{3}$ Tuti Kurnia \\ ${ }^{1,2}$ Keuangan dan Perbankan Syariah, Jurusan Akuntansi, Politeknik Negeri Medan \\ ${ }^{3}$ Ekonomi Syariah, Fakultas Ekonomi dan Bisnis, Universitas Djuanda Bogor \\ E-mail:marlyafatira@polmed.ac.id, rizwit@gmail.com, tuti.kurnia@unida.ac.id
}

\begin{abstract}
This research identifies the needs of cattle breeders for Islamic financing for cattle business development to provide solutions to problems faced by breeders in Deli Serdang Regency, North Sumatra, especially in obtaining access to capital through Islamic financial institutions. The condition of the breeders included in the non-bankable criteria and did not have the 5 C criteria (character, capacity, collateral, capital, and conditions of economic), which are the main requirements for distribution of financing. One way to provide a solution to this problem is by providing easy access for farmers to obtain financing from LKMS with the most appropriate financing schemes and models for farmer business activities. In order to reach this stage, it is necessary to identify the needs of breeders. The research method used is a qualitative approach. Data were collected based on primary sources in the form of interviews with breeders, LKMS around Deli Serdang Regency. The results showed the main needs (needs) of breeders in managing their livestock business to be successful where the availability of capital during the maintenance period, the need for knowledge and skills in processing potential waste from livestock manure to become business and additional income from livestock management, the availability of routine health assistants. Conduct visits to help and provide counseling and control the health of livestock. The Islamic financing model for cattle breeders shows very promising business potential and opportunities for both parties of Islamic cooperatives and cattle breeders. The welfare opportunities formed in a multiplier manner from the sharia financing model for cattle breeders and sharia cooperatives based on investment with a yield within 42 months reach an equivalent rate of $72.5 \%$.
\end{abstract}

Keywords: Farmers Financing; Mudharabah; Ta'awun; Sharia Cooperatives

DOI :10.15575/as.v22i2.9684 
Abstrak: Penelitian ini adalah tentang identifikasi Kebutuhan Peternak Lembu akan pembiayaan Syariah untuk Pengembangan Usaha ternak lembu untuk memberikan solusi atas masalah yang dihadapi peternak di Kabupaten Deli Serdang Sumatera Utara khususnya dalam perolehan akses permodalan melalui lembaga keuangan syariah. Keadaan peternak yang masuk dalam kriteria non bankable, dan belum memiliki kriteria 5 C (character, capacity, collateral, capital and condition of economic) yang menjadi syarat utama penyaluran pembiayaan. Salah satu cara untuk memberikan solusi dari masalah tersebut adalah dengan memberikan kemudahan akses bagi peternak untuk memperoleh pembiayaan dari LKMS dengan skema dan model pembiayaan yang paling tepat untuk kegiatan usaha peternak. Guna mencapai tahap tersebut, maka diperlukan identifikasi Kebutuhan Peternak. Metode penelitian yang digunakan adalah pendekatan kualitatif. Data dikumpulkan berdasarkan sumber primer berupa hasil wawancara kepada peternak, LKMS disekitar Kabupaten Deli Serdang. Hasil penelitian menunjukkan Kebutuhan utama (Kebutuhan) dari peternak dalam mengelola usaha ternaknya agar berhasil adalah Ketersediaan modal selama masa pemeliharaan, kebutuhan akan pengetahuan dan keterampilan dalam mengolah potensi limbah dari kotoran ternak untuk menjadi usaha dan pendapatan tambahan dari pengelolaan ternak, Ketersediaan pendamping kesehatan yang rutin melakukan kunjungan untuk membantu dan memberikan penyuluhan serta mengontrol kesehatan dari ternak. Model pembiayaan syariah untuk peternak lembu menunjukkan potensi dan peluang usaha yang sangat menjanjikan bagi kedua belah pihak koperasi syariah maupun peternak lembu. Peluang kesejahteraan yang terbentuk secara multiplier dari model pembiayaan syariah untuk peternak lembu maupun koperasi syariah berdasarkan investasi dengan imbal hasil dalam kurun waktu 42 bulan mencapai ekuivalen rate $72,5 \%$.

Kata-Kata Kunci: Pembiayaan Ternak; Mudharabah; Ta'awun; Lembaga Keuangan Mikro 


\section{Pendahuluan}

Lembaga Keuangan Mikro Syariah (LKMS) merupakan lembaga pembiayaan yang kehadirannya diutamakan untuk membantu pembiayaan bagi masyarakat golongan rendah, atau masyarakat yang melaksanakan usaha mikro membutuhkan modal namun umumnya tidak bankable. LKMS diketahui mempunyai akses yang lebih mudah terhadap kelompok masyarakat mikro, namun, dalam berbagai bidang usaha mikro yang dilaksanakan masyarakat terlihat bahwa keterlibatan LKMS dalam pembiayaan agribisnis masih minim. LKM lebih dominan menyalurkan pembiayaan kepada pedagang kecil. Agribisnis dan peternakan dianggap sebagai bidang yang cenderung tidak aman, berisiko untuk investasi. Padahal bidang agribisnis merupakan bidang yang potensial untuk pengembangan dan kesejahteraan masyarakat suatu negara. Hal ini merupakan satu hal yang mendukung sehingga Kemenristekdikti dalam RIRN s.d. 2045 mencantumkan pertanian sebagai satu bidang unggulan untuk penelitian di Indonesia.

Memperhatikan pentingnya bidang pertanian dalam meningkatkan kesejahteraan masyarakat, maka Sumatera Utara (SUMUT) melalui RPJP SUMUT tahun 20005-2025 mengupayakan untuk menyelesaikan masalah dibidang pertanian rakyat, usaha informal dan usaha kecil dan menengah yang umumnya memilki daya saing yang masih rendah. Permasalahan lainnya adalah kesenjangan antara pertumbuhan penduduk dan pertumbuhan populasi ternak telah menunjukkan defisit daging dan hasil ternak lainnya yang mengganggu ketersediaan protein hewani yang dibutuhkan oleh masyarakat. Pemenuhan kebutuhan protein hewani ini sangat penting karena dia tak dapat digantikan oleh sumbersumber protein lainnya seperti protein tumbuhan dan lain-lain.

Dalam upaya mengatasi permasalahan yang ada maka setiap Kabupaten dan Kota turut menuangkan rencana pembangunan jangkap panjang dan jangka menengah dengan bidang fokus pertanian, termasuk Kabupaten Deli Serdang yang telah menyusun dalam RPJMD tahun 2014-2019. Sampai saat ini bidang pertanian merupakan sumber utama dan leading sector mayoritas penduduk. Dimana program pembangunan meliputi sektor peningkatan produksi serta peningkatan pendapatan petani, perkebunan, perternakan dan nelayan. Kabupaten Deli Serdang juga merupakan lumbung hasil pertanian untuk Propinsi Sumatera Utara.

Mengupayakan terwujudnya senantiasa Deli Serdang sebagai lumbung hasil pertanian dan peternakan khususnya kambing dan lembu maka perlu dilakukan seinergi dari berbagai unsur khususnya dalam upaya mengembangkan usaha mikro msyarakat melalui penyediaan modal kerja dan modal usaha. Hal ini tentunya dapat dilakukan melalui keterlibatan lembaga keuangan khususnya lembaga keuangan mikro syariah.

Berdasarkan data dari OJK per Februari 2019 terdapat 6o LKMS di Indonesia, dari jumlah tersebut di Sumatera Utara terdapat 3 LKMS yaitu: Koperasi LKMS Madani Emas Nusantara di Kecamatan Medan Helvetia, Kota Medan, Koperasi LKMS Pondok Pesantren 
Modern Al Kautsar, Kecamatan Harau Kabupaten Lima Puluh Kota dan Koperasi LKMS Pondok Pesantren Mawaridussalam Kecamatan Batang Kuis, Kabupaten Deli Serdang.

Kehadiran 3 LKMS di Sumatera Utara tentunya terasa kurang, namun hal ini masih dapat dijembatani dengan upaya bersama untuk membentuk LKMS yang sesuai dengan karakteristik dan kebutuhan masyarakat, khususnya peternak di Langkat. Kegiatan Peternakan di Langkat sudah berjalan baik, namun belum maksimal, karena para peternak selaku produsen khususnya peternak kecil perorangan belum memiliki daya tawar yang bagus di pasaran. Beberapa hal yang menjadi permsalahan yang dihadapi peternak adalah: Kesulitan peternak pada permodalan, dan sampai saat ini belum ada lembaga keuangan khusus yang dapat memberikan bantuan permodalan bagi peternak, baik bersifat pinjaman, atau bantuan hibah. Kesulitan akses permodalan tersebut dilatar belakangi oleh dua faktor, pertama usaha peternak memiliki risiko yang tinggi dan membutuhkan waktu 3-6 bulan serta, kedua peternak tidak memiliki kapasitas 5 C (character, capacity, collateral, capital and condition of economic) yang menjadi syarat utama penyaluran pembiayaan atau kredit di lembaga keuangan. ${ }^{1}$

Berdasarkan masalah-masalah di atas hal ini perlu dibuat formula khusus sehingga peternak dapat memperoleh akses dari lembaga keuangan salah satunya memanfaatkan keberadaan LKMS (lembaga keuangan mikro syariah). Ketatnya syarat yang diberlakukan perbankan dapat menjadikan LKMS sebagai lembaga yang dapat memberikan solusi permodalan bagi peternak, keberadaan LKMS yang dapat memberikan kemudahan akses yang lebih mudah khususnya bagi kalangan masyarakat menengah dan bawah. ${ }^{2}$

LKMS di Indonesia sudah banyak dan sudah memiliki tempat yang khusus di masyarakat terbukti dengan pertumbuhan LKMS yang sangat pesat, sesuai dengan kondisi usaha dan kriteria usaha peternak, LKMS dinilai sangat sesuai untuk menjadikan equity spporting bagi usaha mikro kecil dan menengah termasuk nelayan. ${ }^{3} \mathrm{Hal}$ ini sejalan dengan penelitian yang dilakukan oleh Ade Iskandar Nasution ${ }^{4}$, yang menyampaikan bahwa keberadaan KPBSU Syariah telah banyak mampu membantu 4.500 anggota koperasi yang semuanya adalah peternak dan keluarga peternak. Dari Pengelolaan usaha syariah ini koperasi mampu memeperoleh pendapatan sampai dengan 416 juta rupiah. Pendapatan tersebut selanjutnya dikelola dengan mengacu kepada maqasith syariah sehingga konsep dari anggota untuk anggota berhasil mensejahterakan peternak melalui koperasi syariahnya.

\footnotetext{
${ }^{1}$ Tuti Kurnia and A Alhifni, "Ohilaz: Alternatif Model Pembiayaan Untuk Nelayan Buruh Di Jawa," Jurnal Syarikah, 2016, 174 .

${ }^{2}$ Anas Alhifni and Nurul Huda, "Kinerja LKMS Dalam Mendukung Kegiatan Ekonomi Rakyat Berbasis Pesantren (Studi Pondok Pesantren Darut Tauhid Dan BMT Darut Tauhid)," 2015.

${ }^{3} \mathrm{R}$ Trihantana and Anas Alhifni, "Model Kebijakan Dan Perencanaan Pengawasan Lembaga Keuangan Mikro Syariah (STUDI LKMS Di Wilayah Bogor)," Jurnal Syarikah, 2017, 452.

${ }^{4}$ Ade Iskandar Nasution, "Pendekatan Maqashid Al-Syari'ah Dalam Praktik Pembiayaan Di Koperasi Peternak Sapi Bandung Utara (KPSBU) Lembang," Asy Syariah, 2019, 31-38.
} 
Memperhatikan keberhasilan LKMS berbentuk koperasi syariah, maka fenomena selama ini yang menganggap sulit memberikan pembiayaan kepada usaha ternak dikarenakan sangat berisiko mengingat usia hidup ternak bervariasi tentulah bisa diatasi. Ternak kambing usianya adalah 10-15 tahun, dan masa produksi ternak kambing yaitu 150 hari dalam masa mengandung. Ternak kambing akan mencapai masa dewasa usia 3 sampai dengan 15 bulan. Berbagai keadaan tersebut akan mempengaruhi masa pembiayaan untuk usaha ternak ini terutama ketersediaan lembaga yang mampu menjamin pembiayaan selama masa non produktif antara lain berkisar waktu 15 bulan. Berbeda lagi bila ternak lembu, masanya akan mencapai usia 5-10 tahun.

Mohammad Razan Mahrani dan Muhammad Nafik Hadi Ryandono, menyampaikan bahwa melalui pembiayaan syariah dengan akad mudharabah usaha ternak akan berkembang maksimal ${ }^{5}$, investor dapat melakukan pembiayaan melalui penyertaan modalnya dengan cara langsung maupun tidak langsung untuk jangka waktu pembiayaan 6-8 bulan. Pembiayaan mudharabah mudah dikelola dengan mendasarkan kepada kepercayaan dan kekeluargaan.

Pilihan pembiayaan syariah dengan berbagai akad kerjasama yang dapat diaplikasikan dan dikondisikan peruntukannya sesuai kebutuhan masyarakat antara lain peternak menjadikan peluang ini perlu dimanfaatkan dan dikembangkan secara maskimal, misalnya dengan penerapan akad mudharabah, musyarakah al inan, musyarakah mufawaddah untuk kegiatan pengelolaan ternak secara syariah melalui lembaga keuangan mikro syariah berbentuk koperasi syariah. ${ }^{6}$

\section{Metodologi}

Metode yang digunakan pada penelitian ini adalah metode penelitian deskriftif kualitatif. Studi literatur hanya digunakan untuk mendeskripsikan masalah. Penelitian ini menggunakan pendekatan kualitatif karena menginterpretasikan, menyoroti dan menjelaskan suatu fenomena unik dan penelitian ini sulit untuk diukur oleh penelitian dengan kuantitatif, karena berkaitan dengan memahami pengalaman orang-orang terkait dengan fenomena yang terjadi. ${ }^{7}$

Metode kualitatif yang dilakukan adalah Pertama, diskusi kelompok terfokus (focus group discussion/FGD). Kedua, wawancara mendalam tentang sejarah hidup dengan informan kunci dan sejumlah peternak, khususnya peternak lembu, Ketiga,

\footnotetext{
${ }^{5}$ Mohammad Raza Mahrani, and Muhammad Nafik Hadi Ryandono, "Penerapan Prinsip Akad Mudharabah Pada Investasi Syariah Hewan Ternak PT IJADGRUP Rahmat Semesta," Jurnal Ekonomi Syariah Teori Dan Terapan, 2019, 255.

${ }^{6}$ Marlya Fatira AK, .. "Akad Transaksi Syariah." In Ekonomi Syariah, by Dkk Syarifuddin (Bandung: Widina Bhakti Persada Bandung, 2020).

${ }^{7}$ Yusuf A. Muri., Metode Penelitian Kuantitatif, Kualitatif Dan Penelitian Gabungan (Jakarta: Kencana Prenada Media Group, 2017).
} 
wawancara dengan pimpinan Lembaga keuangan syariah mikro; dan Keempat, observasi kegiatan peternak. Metode ini digunakan untuk mendapatkan jawaban Memberikan informasi hasil analisis tentang kebutuhan peternak dan kesesuaiannya dengan LKMS, yang mencakup hambatan dari peternak maupun LKMS.

\section{Identifikasi Kebutuhan Pembiayaan Syariah Peternak Lembu di Deli Serdang}

Pengembangan usaha ternak secara umum masih banyak mengalami kendala, antara lain karena sangat minimnya modal usaha atau dapat dikatakan lemahnya permodalan, keterampilan yang dimiliki para peternak juga termasuk rendah, demikian juga pengetahuan yang dimiliki peternak juga masih rendah, sehingga cenderung pasrah dan menerima kondisi yang ada sambil mengandalkan pada ketersediaan pakan dari alam. ${ }^{8}$

Keadaan ini menjadikan pilihan berternak adalah bentuk pilihan sebagai usaha sampingan selain pekerjaan utama sebagai petani. Hal ini yang menjadikan pilihan menjual ternak jika peternak sewaktu-waktu membutuhkan biaya yang cukup besar? Padahal usaha ternak memiliki potensi untuk menghasilkan pendapatan yang mensejahterakan bagi peternak, terutama jika ada produksi rutin yang dihasilkan misalnya berupa air susu. Pendapatan dari seorang peternak akan dapat diketahui dengan melakukan analisis pendapatan dari hasil usahanya.

\section{Tabel 1}

Rerata Investasi Usaha Ternak Lembu dengan skala per 4 Ekor Lembu

\begin{tabular}{ll}
\hline Investasi Usaha & Jumlah (Rp/Tahun) \\
\hline Pembelian Ternak & 28.000 .000 \\
\hline Kandang dan Peralatan & 1.200 .000 \\
\hline Total & 29.200 .000 \\
\hline
\end{tabular}

Sumber: Olah data wawancara

Berdasarkan keadaan pada tabel 1 dapat diketahui bahwa rerata investasi yang dibutuhkan untuk mengelola usaha ternak jenis lembu jika dihitung berdasarkan skala per 4 ekor adalah Rp29.200.000, dua puluh sembilan juta dua ratus ribu rupiah). Dimana investai tersebut mencakup investasi untuk pembelian ternak dan penyediaan kandang dan peralatan.

\footnotetext{
${ }^{8}$ Rizal Krisna and Endjang Manshur, "Tingkat Pemilikan Sapi (Skala Usaha) Peternakan Dan Hubungannya Dengan Keuntungan Usaha Tani Ternak Pada Kelompok Tani Ternak Sapi Perah Di Desa Tajung Halang Bogor," Jurnal Penyuluhan Pertanian, 2006, 61-64.

${ }^{9}$ Priyono, "Studi Keterkaitan Antara Ikatan Sosial Dengan Pendapatan Dan Efisiensi Usaha Ternak Sapi Potong Di Kabupaten Banjarnegara" (Skripsi, Purwokerto, Fakultas Peternakan Universitas Soedirman, 2008).
} 
Tabel 2

Analisis Biaya Pemeliharaan Ternak Lembu dengan Skala per 4 Ekor

\begin{tabular}{|c|c|}
\hline Kriteria Biaya & Jumlah (Rp/Tahun) \\
\hline $\begin{array}{l}\text { a. Biaya Tetap } \\
\text { * Biaya Penyusutan kandang dan peralatan }\end{array}$ & 250.000 \\
\hline b. Biaya Variabel & \\
\hline - Pakan Hijau & 1.800 .000 \\
\hline - Biaya Obat/suntik vitamin & 640.000 \\
\hline - Biaya Tenaga Kerja & 600.000 \\
\hline c. Penerimaan & \\
\hline * Penjualan Susu per Liter & - \\
\hline * Penjualan Kotoran Ternak & 2.160 .000 \\
\hline Pendapatan Kotor & 2.160 .000 \\
\hline Total Biaya $(a+b)$ & 3.290 .000 \\
\hline Pendapatan Bersih per tahun & $(1.130 .000)$ \\
\hline
\end{tabular}

Sumber: Olah data wawancara

Berdasarkan data pada tabel 2 diketahui bahwa dalam analisis biaya guna melaksanakan pemeliharaan ternak jenis lembu jika dihitung dengan skala per 4 ekor lembu diketahui membutuhkan biaya sebesar Rp3.290.000, (tiga juta dua ratus sembilan puluh ribu rupiah). Biaya tersebut mencakup biaya tetap berupa biaya penyusutan kandang dan peralatan sebesar Rp250.000/tahun. Kemudian biaya variable yang sifatnya sangat kondisional artinya tergantung pada kebutuhan ternak di tahun tersebut, namun jika dibuat rerata biayanya kebutuhan mencakup pakan hijau, biaya obat/suntik vitamin dari ternak yang dilakukan sebanyak 4 kali dalam setahun serta biaya tenaga kerja. Nilai dari biaya variable ini sebesar Rp3.040.000 (tiga juta empat puluh ribu rupiah). Biaya ini tentulah akan menjadi beban yang perlu disiapkan pendanaannya oleh peternak ketika peternak tidak memiliki sumber penerimaan selama masa pembesaran atau penjagaan ternak hingga siap untuk di jual. Selama ini yang terjadi adalah peternak melakukan penjagaan dan menanggung atau mendahulukan kebutuhan ternak yang dijaganya untuk memenuhi seluruh kebutuhan tersebut. Keadaan ini terjadi karena umumnya dari ternak lembu hanya kotoran saja yang dapat dijadikan sebagai sumber pendapatan. Ketika kotoran langsung dijual tanpa diolah lagi maka hal ini pun menjadikan nilai jualnya sangat rendah hanya Rp500/kg.

Perhitungan pendapatan tidak terlepas dari modal yang dikeluarkan untuk menjalankan suatu usaha karena modal yang dikeluarkan dalam bentuk investasi akan mempengaruhi skala usaha yang berdampak langsung pada pendapatan. Menurut Soekartawi, investasi adalah modal yang dikeluarkan untuk usaha sapi perah meliputi biaya pembelian ternak, biaya pembuatan kandang, dan biaya peralatan. Investasi paling besar untuk pembelian ternak lembu yang masih produktif merupakan modal utama dalam usaha peternakan yang secara kuantitas dan kualitasnya akan mempengaruhi 
pendapatan usaha peternak. Hasil ini sesuai dengan penelitian Siregar ${ }^{10}$ bahwa biaya pembelian sapi perah yang semakin tinggi akan memengaruhi nilai pendapatan yang semakin tinggi pula, maka biaya ini nilainya sesuai dengan hasil pendapatan yang diperoleh.

\section{Identifikasi Kebutuhan peternak dalam mengelola usaha ternaknya}

Usaha pengelolaan merupakan suatu kegiatan peternakan dimana peternak dan keluarganya melakukan pemeliharaan ternak yang bertujuan memperoleh hasil dan pendapatan. Ternak lembu yang dilakukan masyarakat di pedesaan pada umumnya merupakan usaha sampingan selain pekerjaan utama dengan tujuan dapat meningkatkan kesejahteraan hidup keluarga mereka. Usaha ternak lembu merupakan usaha yang saat ini banyak dipilih rakyat untuk dibudidayakan. Kemudahan dalam melakukan budidaya serta kemampuan ternak untuk mengkonsumsi limbah pertanian menjadi pilihan utama. Sebagian besar skala kepemilikan lembu di tingkat rakyat masih kecil yaitu antara 5 sampai 10 ekor. Hal ini dikarenakan usaha ternak yang dijalankan oleh rakyat umumnya hanya dijadikan sampingan yang sewaktu-waktu dapat digunakan jika petani peternak memerlukan uang dalam jumlah tertentu. ${ }^{11}$

Permasalahan yang menyebabkan pilihan masyarakat berternak lembu bervariasi, namun umumnya disebabkan karena usaha ternak lembu hanya usaha sampingan dari pekerjaan utama sebagai petani. Selain itu ada juga yang karena diberi amanah oleh orang lain untuk menjaga lembu, sehingga berkembang dan berkembang sehingga menjadi besar dan terasa menguntungkan, karena adanya sistem bagi hasil dari keuntungan pemeliharaan ternak tersebut.

Pilihan peternak mengelola usaha ternak lembu umumnya adalah disebabkan kontribusi yang dihasilkan dari ternak lembu tersebut yang lebih menguntungkan daripada ternak yang lain, kemudian pemeliharaan lembu yang tidak begitu menyulitkan. Pemeliharaan lembu di Kabupaten Deli Serdang ini sudah lama dilakukan oleh masyarakat. Daerah yang masih memiliki banyak daerah hijau dan padang rumput untuk ternak memperoleh makan menjadikan salah satu pilihan yang menjadikan mengelola ternak lembu di daerah ini mudah. Proses pengembalaan ternak lembu menjadi lebih mudah.

Kondisi pada saat ini, dalam usaha pemeliharaan lembu masyarakat masih melakukan dengan cara tradisional. Masyarakat banyak menyerahkan kepada alam. Pengadaan bibit, pemberian makanan, pemeliharaan atau lain sebagainya belum menggunakan teknologi modern. Pemeliharaan lembu yang mereka lakukan hanyalah sebagai usaha

\footnotetext{
${ }^{10}$ Siregar S.A, "Analisis Pendapatan Peternakan Sapi Potong Di Kecamatan Stabat Kabupaten Langkat" (Skripsi, Medan, Departemen Peternakan Fakultas Pertanian Universitas Sumatera Utara, 2009).

${ }^{11}$ Hidayati, "Usaha Pengemukan Ternak Sapi Dalam Upaya Pengembangan Ekonomi Lokal Di Dusun NGemplak Asem, Umbul Martani, Ngeplak Sleman, Yogyakarta." (Yogyakarta:, Yogyakarta: Fakultas Dakwah, Jurusan Pengembangan Masyarakat, Universitas Islam Negeri Sunan Kalijaga, 2009).
} 
sampingan saja dari pekerjaan utama mereka. Dalam usaha pemeliharaan tersebut umumnya tanpa dilandasi ilmu pengetahuan. ${ }^{12}$

Berdasarkan hasil wawancara yang dilakukan kepada peternak diketahui bahwa kebutuhan utama dari peternak dalam mengelola usaha ternaknya agar berhasil adalah: : pertama, Ketersediaan modal selama masa pemeliharaan. kedua, Berbagai kebutuhan yang muncul dimasa pemeliharaan ternak terkadang sulit untuk dipenuhi oleh penjaga ternak karena ketidak tersediaan dana, hal ini menjadikan pinjaman kepada pemilik ternak menjadi salah satu alternatif yang dituju. Ketiga, Kebutuhan akan pengetahuan dan keterampilan dalam mengolah potensi limbah dari kotoran ternak untuk menjadi usaha dan pendapatan tambahan dari pengelolaan ternak keempat, Ketersediaan pendamping kesehatan yang rutin melakukan kunjungan untuk membantu dan memberikan penyuluhan serta mengontrol kesehatan dari ternak secara cuma-cuma. Kelima, Dibutuhkan wadah bersama seperti GAPOKTAN atau Koperasi untuk komunikasi bersama antara peternak sehingga bisa saling membantu, saling mengisi dan saling mendukung dalam berbahagai hal termasuk modal usaha dalam mengelola ternaknya. Kondisi ini sejalan dengan yang disampaikan Yenni Mardasari. ${ }^{13}$

\section{Model Pembiayaan Mikro bagi Peternak untuk Pengembangan Usahanya}

Model Pembiayaan yang umumnya dilakukan dalam mengelola ternak yang terjadi antara pemilik ternak dengan penjaga ternak adalah dengan sistem bagi hasil (Abdurrahman 2015). ${ }^{14}$ Dalam Pembiayaan syariah disebut dengan akad musyarakah (kerjasama). Bila Ternak sepenuhnya dari pihak pertama dan pihak lainnya sebagai pengelola maka disebut sebgai akad mudharabah atau dikenal juga dengan istilah mawah.

Mudharabah berasal dari kata darba, yang berarti memukul atau berjalan sedangkan maksud kata memukul atau berjalan yaitu seseorang yang melakukan aktivitas di bumi dengan bekerja tujuan mencari karunia Allah swt. Secara istilah mudharabah adalah akad kerjasama usaha antara pemilik modal dengan pengelola di mana pihak pemilik menyerahkan 100\% modal, sedangkan pihak lainnya menjadi pengelola. Keuntungan usaha sesuai kesepakatan yang dituangkan dalam kontrak, sedangkan apabila rugi ditanggung oleh pemilik modal apabila kerugian tersebut bukan akibat kelalaian pengelola. Apabila kelalaian pengelola maka pengelola harus bertanggung jawab atas kerugian tersebut. Sedangkan definisi terminologi mudharabah menurut para ulama Fiqh yang dinyatakan oleh Mazhab Hanafiyah sebagaimana kutipan oleh Meki Utami adalah perseri-

\footnotetext{
${ }^{12}$ A.S. Sudarmono, Sapi Potong (Jakarta: Niaga Swadaya, 2008).

${ }^{13}$ Yenni Mardasari, "Perjanjian Bagi Hasil Mawah Lembu Di Kalangan Masyarakat Desa Rabo Kecamatan Seulimum Dalam Perspektif Akad Muḍarabah" (Banda Aceh:, Fakultas Syariah dan Hukum, Universitas Islam Negeri Arraniry Darussalam, 2018).

${ }^{14}$ Abdurrahman, "Praktek Mawah Melalui Mudharabah Dalam Masyarakat Aceh," Premise Law Journal, 2015, 1.
} 
katan dalam mencari keuntungan dengan modal harta dari satu pihak dan pekerjaan (usaha) dari pihak lain.

Modelnya mawah merupakan salah satu bentuk pembiayaan mudharabah dalam bidang peternakan, umumnya pemilik ternak memiliki ternak namun tidak memiliki kemampuan waktu dan pengetahuan dalam memilihara ternak. Keadaan ini menjadikan hadirnya peluang usaha untuk orang lain membantu menjaga ternak tersebut. Dalam pengelolaan dan penjagaan ternak yang telah menjadi milik bersama tersebut hadirlah pembiayaan mudharabah, sehingga da yang dibagihasilkan. Ketentuan umumnya selama ini untuk ternak Jantan, maka ternak akan terlebih dahulu dinilai taksiran nilai uangnya. Misalnya harganya adalah Rpg.000.000, (Sembilan juta rupiah), maka setelah itu kedua belah pihak melakukan ijab qabul penyerahan hewan ternak untuk dikelola oleh pemelihara. Setelah satu atau dua tahun hewan tersebut dijual dengan harga Rp15.000.000, (lima belas juta rupiah), maka diperoleh keuntungan sebesar Rp6.000.000, yang selanjutnya dibagi dua antara pemilik ternak dan orang yang memelihara. Nilai pembagian ini akan dilakukan setelah bagian milik peternak (pemodal) telah dikeluarkannya terlebih dahulu modal dari pemilik ternak yaitu harga taksiran awal yang telah disepakati oleh kedua belah pihak. Mengenai lembu betina pembagiannya berupa anak lembu, anaknya itu dibagi antara pemilik lembu dengan pemelihara.

Berdasarkan hasil wawancara dengan Idis, diketahui bahwa praktek mawah lembu sudah menjadi tradisi yang memasyarakat secara turun temurun. Biasanya pernyataan perjanjian bagi hasil mawah yang dilakukan masyarakat secara lisan. Keadaan ini terjadi karena pemilik ternak biasanya dari orang berpenghasilan menengah ke atas yang tinggal di daerah yang berbeda, bisa di Kota akan berbeda desa. Mereka memiliki ternak tetapi tidak mampu memelihara sendiri sehingga membutuhkan orang lain untuk memelihara ternaknya. Pengelola ternak yang bertugas menjaga dan memelihara ternak akan mendapatkan keuntungan dari hasil bagi usaha yang telah disepakati sejak awal.

Keuntungan yang disepakati selama ini umumnya 50\%:50\%, artinya dari hasil keuntungan $50 \%$ untuk pemelihara ternak dan $50 \%$ untuk pemilik ternak. Para pemilik modal biasanya mereka yang berpendapatan menengah ke atas, sedangkan yang mengelola usaha atau modal tersebut yaitu mereka yang berpendapatan menengah ke bawah. Secara umum juga diketahui bahwa para pemilik modal bisanya tinggal berjauhan, bisa berbeda desa atau berbeda kota dengan penjaga ternaknya. Keadaan inilah yang menghadirkan berbagai peluang usaha dalam berbagi hasil secara syariah.

Di sisi lain, disampaikan oleh Mail selaku pemelihara ternak menjelaskan bahwa dalam perjanjian bagi hasil menjaga ternak, terkadang diperoleh beberapa masalah yang seharusnya telah difikirkan dan disepakati atau dibincangkan semula dari awal kegiatan kerjasama dilakukan. 
Beberapa kendala tersebut adalah ketika proses pemeliharaan, misalnya lembu yang dipelihara mengalami sakit, sehingga pemelihara memerlukan uang yang besar untuk membiayainya, sedangkan ia tidak memiliki uang tunai atau harta lain. Kondisi lain saat ada lembu yang hilang, atau mati maka pemilik dan pemelihara tidak mendapatkan hasil dan mengalami kerugian. Berbagai keadaan tersebut perlulah diantisipasi sejak awal perjanjian agar terhindar dari hal-hal yang tidak diinginkan, serta siap menghadapi setiap risiko yang mungkin terjadi kedepannya.

Memperhatikan hasil dari wawancara dan penelitian terhadulu dapat diketahui bahwa lembaga keungan mikro syariah (LKMS) dapat berperan serta dalam penyediaan pembiayaan untuk jangka waktu 2-3 tahun dengan memberikan pembiayaan dengan akad mudharabah dengan pemelihara ternak atau peternak, serta memberikan jaminan asuransi dengan akad ta'awun tolong menolong sehingga akan terbentuk kebersamaan dalam kegiatan usaha ternak.

Model mekanisme pembiayaan LKMS kepada peternak lembu yang dapat diterapkan adalah Mudharabah untuk koperasi Syariah memberikan modal untuk peternak sebagai anggota koperasi untuk menerima modal awal pembelian ternak betina yang masih gadis (usia 10-15 bulan) dengan nilai Rp5.000.000 (lima juta rupiah), pembuatan kendang 300.000 (tiga ratus ribu), dan penyediaan vitamin ternak dan periksa ternak Rp150.000 (seratus lima puluh ribu) untuk satu tahun. Anggaplah total modal yang dibutuhkan Rp5.450.000 (lima juta empat ratus lima puluh ribu rupiah) untuk masa pembiayaan 24 bulan. Setelah peternak menerima ternak sesuai nilai dan kesepakatan serta modal untuk membuat kendang sesuai kesepakatan, maka peternak mulai memelihara ternak lembu nya, penyediaan pakan ternak diambil dari alam dengan mengangon selama masa kurang lebih 6 bulan maka ternak lembu tersebut sudah dapat dikawinkan (usia 15-18 bulan, usia lembu betina untuk dikawinkan) untuk pertama kalinya disatukan dengan lembu jantan hingga berhasil bunting. Setelah berhasil bunting lembu betina tersebut akan menjalani masa bunting sampai 9 bulan, sehingga lembu betina akan melahirkan anak pada usia pembiayaan bulan ke-14, ternak lembu melahirkan anggap 1 ekor anak lembu kemudian diperlihara sampai usia gadis 10 bulan dan bernilai jual minimal Rp5.500.000 (lima juta lima ratus ribu rupiah), saat ini pembiayaan masuk bulan ke-24, dan telah menghasilkan keuntungan Rp Rp5.500.000 (lima juta lima ratus ribu rupiah) yang dapat dibagi hasilkan antara koperasi syariah dengan peternak sebagai anggota koperasi dengan nisbah bagi hasil sesuai kesepakatan awal misalnya 40\% untuk Pemilik Modal dan 60\% untuk peternak, maka dalam hal ini di bulan ke-25 pembiayaan dapat diberikan bagi hasil kepada Koperasi sebesar 40\% x Rp5.500.000 = Rp2.200.000, (dua juta dua ratus ribu rupiah) dan Rp3.300.000, (tiga juta tigas ratus ribu rupiah) diterima petani sebagai bagian bagi hasilnya.

Lantas dari kondisi tersebut muncul pilihan lagi antara peternak dan Pemilik Modal (Koperasi Syariah), yaitu: pertama, peternak mengakhiri pembiayaan kerjasama mudha- 
rabah-nya dengan koperasi Syariah. Sehingga peternak mengembalikan Modal awal Rp5.000.000 (lima juta rupiah) disertai bagian bagi hasil untuk koperasi syariah sebesar Rp2.200.000 (dua juta dua rastus ribu rupiah), atau total dana yang dikembalikan untuk mengakhiri pembiayaan kerjasama adalah Rp7.200.000 (tujuh juta dua ratus ribu rupiah). Alternative kedua adalah Peternak dan koperasi Syariah melanjutkan pembiayaan dengan akad yang berbeda yaitu musyarakah inan. ${ }^{15}$ Pada Musyarakah inan ini dilakukan kerjasama antara peternak dan koperasi syariah dimana kedua belah pihak memiliki modal namun dengan porsi yang berbeda. Kondisi ini terjadi dengan modal yang dimiliki peternak dihitung dan modal koperasi yang awal dihitung sebagai berikut:

\section{Tabel 3}

Nilai Kepemilikian Koperasi Syariah dan Peternak diakhir tahap I Masa Pembiayaan

\begin{tabular}{llll}
\hline Uraian & $\begin{array}{l}\text { Nilai kepemilikan } \\
\text { Koperasi Syariah }\end{array}$ & $\begin{array}{l}\text { Nilai Kepemilikan } \\
\text { Peternak }\end{array}$ & $\begin{array}{l}\text { Total Modal } \\
\text { Terkini }\end{array}$ \\
\hline Modal awal lembu Gadis & Rp5.000.000 & - & - \\
\hline Anak Lembu & Rp2.200.000 & Rp3.300.000 & 5.500 .000 \\
\hline Lembu Betina Produktif & - & Rp3.500.000 & 8.500 .000 \\
\hline Kandang & & Rp 600.000 & 600.000 \\
\hline Total Modal & Rp7.200.000 & Rp7.400.000 & 14.600 .000 \\
\hline
\end{tabular}

Sumber: Kalkulasi Prediksi Nilai Hasil

Berdasarkan tabel tersebut terlihat bahwa setelah pembiayaan 24 bulan atau 2 tahun, peternak yang mulanya tanpa modal sekarang memiliki kontribusi modal sebesar 50,68\% dari total modal bersama Rp14.600.000 (empat belas juta enam ratus ribu rupiah) yang dimiliki saat ini, sedangkan pihak koperasi Syariah kini memiliki modal lebih kecil yaitu $49,32 \%$ dari total modal yang akan disertakan. Keadaan ini menjadikan nisbah bagi hasil baru akan disepakati sesuai dengan besaran kontribusi modal dan risiko pengelolaan usaha, dan kontribusi kerja antara kedua belah pihak. Nilai nisbah baru yang disepakati misalnya menjadi 85\% (Peternak): 15\% (Koperasi Syariah) untuk masa pembiayaan 18 bulan kedepan, maka setelah 12 bulan kedepan prediksi hasil kerjasama akan menjadi: Indukan Betina memiliki anak lembu baru 1 ekor, ketika masa pembiayaan ke-18 sudah bersusia 4 bulan dan bernilai jual seharga Rp6.500.000 (enam juta lima ratus ribu rupiah). Kemudian anak pertama Indukan di akhir usia pembiayaan ke-18 bulan sudah bernilai 8.500.000 (delapan juta lima ratus ribu rupiah). Diakhir masa pembiayaan, bulan ke-19 pembiayaan diakhir dengan kondisi asset peternak dan koperasi menjadi:

\footnotetext{
${ }^{15}$ Anriza Witi Nasution and Marlya Fatira AK, Pengantar Perbankan Syariah Untuk Profesional Muda (Yogyakarta: Andi Offset, 2013).
} 
Tabel 4

Nilai Kepemilikian Koperasi Syariah dan Peternak diakhir tahap II Masa Pembiayaan

\begin{tabular}{|c|c|c|c|}
\hline Uraian & $\begin{array}{l}\text { Nilai kepemilikan } \\
\text { Koperasi Syariah }\end{array}$ & Kepemilikan & $\begin{array}{l}\text { Total Modal } \\
\text { Terkini }\end{array}$ \\
\hline Indukan Betina & Rp5.000.000 & 3.500 .000 & 8.500 .000 \\
\hline Anak Lembu ke-2 & Rp975.000 & Rp5.525.000 & 6.500 .000 \\
\hline $\begin{array}{l}\text { Lembu Betina } \\
\text { Produktif (anak ke-1 } \\
\text { dari Indukan) }\end{array}$ & $\begin{array}{l}=2.200 .000+450.000 \\
=2.650 .000\end{array}$ & $\begin{array}{l}=\text { Rp3 } .300 .000+2.550 .000 \\
=R p 5.850 .000\end{array}$ & 8.500 .000 \\
\hline Kandang & - & Rp 900.000 & 900.000 \\
\hline Total Modal & Rp8.625.000 & Rp15.775.000 & 24.400 .000 \\
\hline
\end{tabular}

Sumber: Kalkulasi Prediksi Nilai Hasil

Berdasarkan tabel 4 terlihat kondisi terkini yang dimiliki oleh peternak diakhir masa pembiayaan tahap II adalah kepemilikan Koperasi Syariah Rp8.625.00o dan Kepemilikan Peternak Rp15.775.000. Keadaan ini menunjukkan kesejahteraan yang terbentuk bagi peternak lembu setelah melakukan kemitraan dalam pembiayaan Syariah selama 3,5 tahun atau ( 42 bulan) yaitu dari tidak ada asset menjadi memiliki asset senilai 15.775 .000 (lima belas juta tujuh ratus tujuh puluh lima ribu rupiah). Mulanya tanpa kepemilikan seekor ternak pun kini memiliki 1 ekor indukan dan 1 ekor lembu betina usia produktif dengan nilai total Rp15.000.000 (lima belas juta Rupiah). Diakhir masa pembiayaan tahap II Peternak dapat mengembalikan modal koperasi Syariah lengkap dengan nisbah bagi hasil untuk koperasi Syariah dengan menjual 1 ekor Lembu Betina Produktif (anak ke-1 dari Indukan). Koperasi Syariah dalam pembiayaan ini mulanya bermodal 5.000 .000 (lima juta rupiah), setelah pembiayaan 42 bulan memperoleh hasil Rp3.625.000 (tiga juta enam ratus dua puluh lima ribu rupiah), investasi tersebut senilai memberikan imbal hasil dengan ekuivalen rate $72,5 \%$.

Ilustrasi model pembiayaan Syariah untuk peternak lembu ini menunjukkan potensi dan peluang usaha yang sangat menjanjikan bagi kedua belah pihak koperasi syariah maupun peternak lembu. Terlihat peluang kesejahteraan yang terbentuk secara multiplier dari model pembiayaan syariah untuk peternak lembu ini. Kiranya janji Allah dalam distribusi harta melalui pembiayaan syariah nyata terwujud salah satunya melalui pembiayaan koperasi syariah untuk peternak lembu ini.

\section{Simpulan}

Kebutuhan utama dari peternak dalam mengelola usaha ternaknya agar berhasil adalah Ketersediaan modal selama masa pemeliharaan, Kebutuhan akan pengetahuan dan keterampilan dalam mengolah potensi limbah dari kotoran ternak untuk menjadi usaha dan pendapatan tambahan dari pengelolaan ternak, Ketersediaan pendamping 
kesehatan yang rutin melakukan kunjungan untuk membantu dan memberikan penyuluhan serta mengontrol kesehatan dari ternak secara cuma-cuma dan bibutuhkan wadah bersama seperti GAPOKTAN atau Koperasi untuk komunikasi bersama antara peternak sehingga bisa saling membantu, saling mengisi dan saling mendukung dalam berbahagai hal termasuk modal usaha dalam mengelola ternaknya. Lembaga keuangan mikro syariah (LKMS) dapat berperan serta dalam penyediaan pembiayaan untuk jangka waktu 2-3 tahun dengan memberikan pembiayaan dengan akad mudharabah dengan pemelihara ternak atau peternak, serta memberikan jaminan asuransi dengan akan ta'awun tolong menolong sehingga akan terbentuk kebersamaan dalam kegiatan usaha ternak.

\section{Acknowledgments}

Ucapan terima kasih diucapkan kepada Direktur Politeknik Negeri Medan dan Jajarannya yang telah mendanai penelitian ini dengan menggunakan dana DIPA Politeknik Negeri Medan.

\section{Daftar Pustaka}

A. Muri., Yusuf. Metode Penelitian Kuantitatif, Kualitatif Dan Penelitian Gabungan. Jakarta: Kencana Prenada Media Group, 2017.

Abdurrahman. "Praktek Mawah Melalui Mudharabah Dalam Masyarakat Aceh." Premise Law Journal, 2015, 1.

Alhifni, Anas, and Nurul Huda. "Kinerja LKMS Dalam Mendukung Kegiatan Ekonomi Rakyat Berbasis Pesantren (Studi Pondok Pesantren Darut Tauhid Dan BMT Darut Tauhid)," 2015.

Fatira AK, Marlya. .. "Akad Transaksi Syariah." In Ekonomi Syariah, by Dkk Syarifuddin. Bandung: Widina Bhakti Persada Bandung, 2020.

Hidayati. "Usaha Pengemukan Ternak Sapi Dalam Upaya Pengembangan Ekonomi Lokal Di Dusun NGemplak Asem, Umbul Martani, Ngeplak Sleman, Yogyakarta." Yogyakarta: Fakultas Dakwah, Jurusan Pengembangan Masyarakat, Universitas Islam Negeri Sunan Kalijaga, 2009.

Krisna, Rizal, and Endjang Manshur. "Tingkat Pemilikan Sapi (Skala Usaha) Peternakan Dan Hubungannya Dengan Keuntungan Usaha Tani Ternak Pada Kelompok Tani Ternak Sapi Perah Di Desa Tajung Halang Bogor." Jurnal Penyuluhan Pertanian, 2006, 61-64.

Kurnia, Tuti, and A Alhifni. "Ohilaz: Alternatif Model Pembiayaan Untuk Nelayan Buruh Di Jawa." Jurnal Syarikah, 2016, 174. 
Marly Fatira Ak, Anriza Witi Nasution, Tuti Kurnia, Identifikasi Kebutuhan Pembiayaan Syariah... | 351

Mahrani, Mohammad Raza, and Muhammad Nafik Hadi Ryandono. "Penerapan Prinsip Akad Mudharabah Pada Investasi Syariah Hewan Ternak PT IJADGRUP Rahmat Semesta." Jurnal Ekonomi Syariah Teori Dan Terapan, 2019, 255.

Mardasari, Yenni. "Perjanjian Bagi Hasil Mawah Lembu Di Kalangan Masyarakat Desa Rabo Kecamatan Seulimum Dalam Perspektif Akad Muḍarabah." Fakultas Syariah dan Hukum, Universitas Islam Negeri Arraniry Darussalam, 2018.

Nasution, Ade Iskandar. "Pendekatan Maqashid Al-Syari'ah Dalam Praktik Pembiayaan Di Koperasi Peternak Sapi Bandung Utara (KPSBU) Lembang." Asy Syariah, 2019, 31-38.

Nasution, Anriza Witi, and Marlya Fatira AK. Pengantar Perbankan Syariah Untuk Profesional Muda. Yogyakarta: Andi Offset, 2013.

Priyono. "Studi Keterkaitan Antara Ikatan Sosial Dengan Pendapatan Dan Efisiensi Usaha Ternak Sapi Potong Di Kabupaten Banjarnegara." Skripsi, Fakultas Peternakan Universitas Soedirman, 2008.

S.A, Siregar. "Analisis Pendapatan Peternakan Sapi Potong Di Kecamatan Stabat Kabupaten Langkat." Skripsi, Departemen Peternakan Fakultas Pertanian Universitas Sumatera Utara, 2009.

Sudarmono, A.S. Sapi Potong. Jakarta: Niaga Swadaya, 2008.

Trihantana, R, and Anas Alhifni. "Model Kebijakan Dan Perencanaan Pengawasan Lembaga Keuangan Mikro Syariah (STUDI LKMS Di Wilayah Bogor)." Jurnal Syarikah, 2017, 452. 
352 | Asy-Syari'ah Vol. 22 No.2, Desember 2020

[Halaman ini sengaja dikosongkan] 
Asy-Syari'ah (P-ISSN: 2086-9029 E-ISSN: 2654-5675) is a periodical scientific journal that publishes various results of studies and research, literature review, and other scientific works whose scope covers the field of Islamic law/sharia, law and society in monodisciplinary, interdisciplinary, and multidisciplinary manners. The journal aims to expand and create innovative concepts, theories, paradigms, perspectives and methodologies in the above said scope. The Journal is published twice a year (june and december) by Faculty of Shariah and Law, Sunan Gunung Djati State Islamic University Bandung in collaboration with Asosiasi Sarjana Syariah Indonesia (ASSYI).

\section{EDITORIAL OFFICE:}

Fakultas Syariah dan Hukum UIN Sunan Gunung Djati Bandung J1. Raya A.H. Nasution No. 105 Cibiru Kota Bandung, 40614

Tlp/Fax: +022-7802278 Faks. 022-7802278

Website http://journal.uinsgd.ac.id/index.php/asy-syariah/index

E-mail: Jurnalasy-syariah@uinsgd.ac.id 